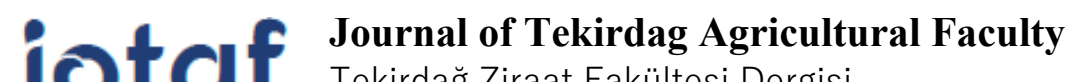 \\ Tekirdağ Ziraat Fakültesi Dergisi
}

\section{The Effect of Building Orientation on Utilization of Solar Energy in Dairy Cattle Barns}

\author{
Süt Sığırı Barınaklarında Güneş Enerjisinden Yararlanmada Yönlendirmenin Etkisi
}

\author{
Hatice DELICE ${ }^{1 *}$, Erkan YASLIOGLU ${ }^{2}$
}

\begin{abstract}
In Turkey and the World, energy demand is continuously increased. In addition to the rapid depletion of fossil fuel resources used to supply the energy needs, ambient temperatures is risen, glaciers are melt and natural disasters are occured in our planet. In addition, people, animals and plants are greatly damaged due to the adverse effects of soil, water and air pollution. Solar energy is renewable, clean and easily accessible energy. Our country is more advantageous in terms of solar energy potential in comparison to many other countries and benefitting from this potential is very important. With the increasing importance of renewable energy sources, photovoltaic (PV) panels, which are able to convert solar energy directly into electrical energy, are not polluting the environment and easy to implement, are become more common. The inclination angle and position of the photovoltaic panels are the parameters that directly affect the production of electrical energy. Electrical energy is extensively used in agricultural production activities, as in every field. Especially, in animal production systems, the cost of electrical energy is an important input due to the high mechanization and the use of automation. This study was carried out in the dairy cattle barn with a capacity of 50 head in Bursa province. It was aimed to determine the amount of electrical energy produced by photovoltaic (PV) panels, located on the barn roof in four different directions (NorthSouth, East-West, Northeast-Southwest, Northwest-Southeast), and also to find out whether produced energy is sufficient or not to meet the energy requirement of the barn. The electrical energy produced by the panels to be placed on the roofs was determined by using PVSOL software. According to the results, the amount of electrical energy produced from the panels with North-South (N), East-West (E), Northeast-Southwest (NE) and NorthwestSoutheast (NW) orientation was determined as $179.453,0 \mathrm{kWh}, 159.655,0 \mathrm{kWh}, 175.950,0 \mathrm{kWh}$ and $138.245,0$ $\mathrm{kWh}$, respectively. The annual electrical energy requirement of the barn with 50 head capacity was calculated as $25.200,0 \mathrm{kWh}$. In this case, it was calculated that the energy produced from the N, E, NE and NW orientations met the requirements of the barn by 5 to 7 times.
\end{abstract}

Keywords: Dairy Cattle, Orientation, Photovoltaic Panel, PVSOL, Solar Energy

\footnotetext{
1*Sorumlu Yazar/Corresponding Author:. Hatice Delice, Bursa Uludag University, Graduate School of Natural and Applied Science, Bursa, Turkey. E-mail: hatidelice1@gmail.com (iD) OrcID: 0000-0002-0781-2154

${ }^{2}$ Erkan Yaslioglu, Bursa Uludag University, Agricultural Faculty, Department of Biosystem Engineering, Turkey. E-mail: yasli@uludag.edu.tr (iD OrcID: 00000002-3865-7863.

Atıf/Citation: Delice H, Yaslıoglu E. The effect of building orientation on utilization of solar energy in dairy cattle barns. Tekirda ̌̆ Ziraat Fakültesi Dergisi, 18 (3), 419-427.

CBu çalışma Tekirdağ Namık Kemal Üniversitesi tarafından Creative Commons Lisansı (https://creativecommons.org/licenses/by-nc/4.0/) kapsamında yayınlanmıştır. Tekirdağ 2021
} 


\section{Öz}

Türkiye'de ve Dünya'da enerji talebi sürekli artmaktadır. Gezegenimizde enerji ihtiyacını karşılamak için kullanılan fosil yakıt kaynaklarının hızla tükenmesinin yanı sıra ortam sıcaklıkları yükselmekte, buzullar erimekte ve doğal afetler meydana gelmektedir. Ayrıca toprak, su ve hava kirliliğinin olumsuz etkilerinden dolayı insanlar, hayvanlar ve bitkiler büyük ölçüde zarar görmektedir. Güneş enerjisi, tükenmeyen, temiz ve kolay erişilebilen bir enerjidir. Ülkemiz sahip olduğu güneş enerjisi potansiyeli bakımından birçok ülkeye göre şanslı durumdadır ve söz konusu potansiyelin değerlendirilmesi oldukça önemlidir. Yenilenebilir enerji kaynaklarının önem kazanmasıyla birlikte güneş enerjisini doğrudan elektrik enerjisine dönüştürebilen, çevreyi kirletmeyen ve uygulanması kolay olan fotovoltaik (PV) paneller her geçen gün daha da yaygınlaşmaktadır. Fotovoltaik panellerin eğim açısı ve konumu elektrik enerji üretimini doğrudan etkileyen parametrelerdir. Her alanda olduğu gibi tarımsal üretim faaliyetlerinde de elektrik enerjisi yoğun olarak kullanılmaktadır. Özellikle hayvansal üretim sistemlerinde, yüksek mekanizasyon ve otomasyon kullanımı nedeniyle elektrik enerjisi maliyeti, işletmeler için önemli bir girdi olarak ortaya çıkmaktadır. Bu çalışma, Bursa ilinde 50 baş kapasiteli süt sığırcılığı ahırında gerçekleştirilmiştir. Farklı yönlerde çatıya gelen güneş ışığının nasıl değiştiğini ortaya koymak amacıyla barınak 4 farklı (KuzeyGüney, Doğu-Batı, Kuzeydoğu-Güneybatı, Kuzeybatı-Güneydoğu) yönde konumlandırılarak her bir yön için üretilen elektrik enerjisi belirlenmiştir. Çatılara yerleştirilecek panellerin ürettiği elektrik enerjisi PVSOL yazılımı kullanılarak belirlendi. Elde edilen sonuçlara göre Kuzey-Güney (K), Doğu-Batı (E), Kuzeydoğu-Güneybatı (KD) ve Kuzeybatı-Güneydoğu (KB) yönelimli panellerden üretilen elektrik enerjisi miktarı sirasıly $179.453,0 \mathrm{kWh}$, $159.655,0 \mathrm{kWh}, 175.950,0 \mathrm{kWh}$ ve $138.245,0 \mathrm{kWh}$ olarak belirlenmiş̧ir. 50 baş kapasiteli ahırın yıllık elektrik enerjisi ihtiyacı 25.200,0 kWh olarak hesaplanmıştır. Bu durumda K, D, KD ve KB yönlerinden üretilen enerjinin ahırın ihtiyacını 5 ila 7 kat karşıladığı hesaplanmıştır.

Anahtar Kelimeler: Süt sığırı, Yönlendirme, Fotovoltaik panel, PVSOL, Güneş enerjisi 


\section{Introduction}

In Turkey and the World, energy demand is continuously increased. In addition to the rapid depletion of fossil fuel resources used to supply the energy needs, ambient temperatures had risen, glaciers are melted and natural disasters have occurred in our planet.

Additionally, people, animals and plants are greatly damaged due to the adverse effects of soil, water and air pollution. To mitigate all these negative effects, solar energy, which is not cause environmental problems and is not threaten the lives of living creatures, is of great importance for the future of human beings as a clean, reliable and sustainable renewable energy source.

One of the most common Renewable Energy Sources on earth is solar energy. From this energy, electricity and heat can be obtained. In addition, since using solar energy is more costly than using fossil fuel today, only $0.04 \%$ of the incoming solar energy potential is used (Mohtasham, 2015).

Due to the shape of the earth (geoid), the angle of the sun rays to fall on the earth differs according to the coordinates. For this reason, the annual insolation amounts of the coordinates where a place where photovoltaic panel (PV) planning will be made directly affects the energy obtained from the panel (Thomas, 2003).

Turkey due to its geographical location is relatively advantageous in terms of solar energy and potential renewable energy sources. According to the Turkey's Solar Energy Potential Atlas (GEPA), the annual sunshine duration is $2.737,0$ hours (daily total of 7.5 hours) per year, the total incident solar energy $1.527,0 \mathrm{kWh} \mathrm{m}^{-1} . \mathrm{year}^{-1}$ corresponding to $4.2 \mathrm{kWh} \mathrm{m}^{-1}$ per day ${ }^{-1}$, total annual sunshine duration is 6.8 hours, annual total incoming solar energy is $1.394,0 \mathrm{kWh} \mathrm{m}^{-1}$.year ${ }^{-1}, 3.8 \mathrm{kWh} \mathrm{m}^{-1}$ per day-1 (Anonymous, 2015a).

Solar energy, compared with other renewable energy sources, energy sources with the highest potential in Turkey (EEG, 2016). Turkey's potential annual electricity production from solar energy is estimated to be at least 500 GW (Bayraktar, 2016).

When the Turkey's solar energy potential distribution is examined by region, it can be easily seen that the Marmara region is on 6th ranks with the value of $1.168,0 \mathrm{kWh} \mathrm{m}^{-1} \mathrm{year}^{-1}$ (Anonymous, 2014). On the other hand, in Turkey, solar panels might be used in every region to supply sufficient electric power (Türkboyları and Yüksel, 2021).

The number of dairy cattle in Turkey was increased from 5.969.047,0 head in 2017 to 6.337.906,0 in 2018 with $6.2 \%$ rate of increase. According to the 2018 data, Bursa province has 236.604 head cattle (Tuik, 2019). Bursa, located in the southern Marmara Region of Turkey, is one of the provinces with the largest dairy cattle barns in the region, besides being rich in dairy farms (Yaslioglu and Ilhan, 2016). Dairy cattle management is one of the most suitable sectors for agricultural investment in Bursa because of the ratio of meeting the requirement of forage silage is $90-99 \%$ and the ratio of meeting the need of hay is between $80-85 \%$. Bursa is also at the forefront in terms of both the number of milk processing plants (establishments) and its capacity. Considerable part of the milk needs of the companies that produce for the national market is provided from Bursa. Therefore, there is no market problem for dairy cattle breeders in Bursa (Anonymous, 2017).

It is possible to use solar energy efficiently in almost every region of the Turkey. Nowadays, solar energy systems in Turkey are often used to meet the needs of the domestic water heating and buildings heating. In recent years, solar energy systems to support heating have become increasingly common. The use of solar energy to meet the hot water requirement in swimming pools and various facilities, cooling buildings, drying plants and power production plants is increased (Anonymous, 2015b).

With renewable energy sources becoming more important, photovoltaic (PV) panels, which can convert solar energy directly to electrical energy, nonpolluting and easy applicable, are becoming widespread. The angle and position of the photovoltaic panels are the parameters that directly affect the its electrical energy production capacity.

Photovoltaic panels (PV) transform solar energy into electrical energy with an efficiency of 6-20\%, depending on the semiconductor material in their structure. It has been stated that panel inclination angle, shading, dusting, 

solar radiation intensity and temperature are effective on the efficiency of photovoltaic panels (Irwanto et al., 2014; Bhol et al., 2015).

As in all fields, electrical energy is also used extensively in agricultural production activities. Especially in animal production systems, the cost of electrical energy emerges as an important input for enterprises due to the use of high mechanization and automation (Peterson, 2008).

There are several studies that examines the structural aspect of cattle houses in various regions of Turkey (Soyak et al., 2007, Ozyürek et al. 2014, Kurc and Kocaman, 2016). But there is little study on the effect of site selection on energy use efficiency of cattle barn. Therefore, this study was carried out in order to find the appropriate orientation according to the amount of electrical energy produced by the PV panels placed on the roof in order to meet the energy consumed in a dairy cattle barn with a capacity of 50 head in Bursa and to determine the fulfilment ratio of the energy demand of the barn.

\section{Materials and Methods}

\subsection{Experiment site and barn plan}

In this study, a dairy cattle barn with a capacity of 50 heads planned to be established in Bursa Uludağ University Research and Application Center in the Marmara Region was used as study material.

Firstly, the amount of electrical energy consumed by the farm was calculated based on assumption of $42 \mathrm{kWh}$ energy consumption per animal per month (Collar et al., 2000). Accordingly, the annual amount of electricity to be consumed was calculated based on the animal number of the enterprise in the study.

Collar et al., (2000) conducted a study in California to increase energy efficiency in dairy cattle enterprises, promote energy savings and reduce energy costs in dairy farms. In this study, monthly milk production and electricity usage data were collected for 12 months in 42 barns that have an average of 984 cows. As a result of the study, they determined that approximately $42 \mathrm{kWh}$ of electricity was used per cow per month.

In order to determine sunlight variations on the roof, it was assumed that the barns were positioned in 4 different directions as North-South (N), East-West (D), Northeast-Southwest (NE), and Northwest-Southeast (NW) and, accordingly the amount of annually electrical energy for each direction was determined.

The dimensions of the 50 head dairy cattle barn planned to be built are $16.70 \mathrm{~m} * 76 \mathrm{~m}$, and the roof area is $1.429,0 \mathrm{~m}^{2}$. Barn section is given in Figure 1. In the study, it is planned to cover the entire roof with a solar panel.

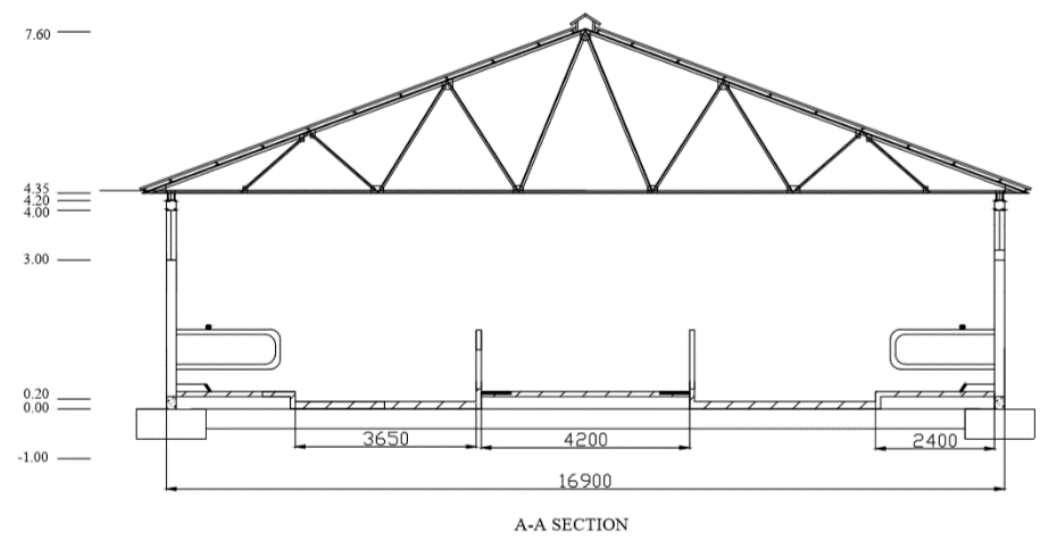

Figure 1. Barn section

\subsection{Design of solar panels}

The amount of electrical energy produced by the panels on the roofs was calculated using PVSOL software. The PV panel capacity is $320 \mathrm{wp}$ power and dimensions are $1.652,0 \times 1.306,0 \times 50,0 \mathrm{~mm}$. The total power of the panels is $160 \mathrm{kWp}$. According to the calculations carried out in the PVSOL, it was determined that there is a need 
for 5 invertors. The panel and inverter used were selected from the energy systems companies in the PVSOL software.

PVSOL Premium a PV simulation software is used to design the three-dimensional (3-D) building blocks with solar panels adjusted optimally on shade free regions of the roof with optimum tilt angle (equal to latitude angle) to tap maximum solar radiation and in turn increase the productivity of the system (Sharma and Gidwani, 2017).

It is planned that the direct current (DC) electrical energy produced by the PV panel system will be converted to alternative current (AC) with the help of an inverter and delivered directly to the electrical installation.

In the study, which orientation is more beneficial in terms of solar energy efficiency of the barn planned to be positioned in different direction was analyzed.

\section{Results and Discussion}

PVSOL software was used to calculate solar potential in many areas. For example, Sharma and Gidwani (2017) carried out study on feasibility of grid connected roof mounted solar photovoltaic installations on Rajasthan Technical University campus hostel buildings in India using PV simulation software-PVSOL premium. They concluded that a 234 kilowatts of PV installation can full fill all the Electrical load needs and all the investments made will be returned in a span of eleven years.

Ozden et al., (2020) compare the estimation of three software (PV*Sol, PVsyst, HelioScope) using a whole year field data obtained in Ankara, for five-module types. They stated that the estimation accuracies of the software are reasonable based on comparisons.

The first study on renewable energy use in animal barns was the solar electricity generation and feasibility study of the Delaware poultry farm in April 2005 (Byrne et al., 2005). In this study, feasibility of system was analysed and alternative scenarios and cost conditions were evaluated with simulation model approach. The study shows that solar energy is more economical for poultry producers in certain regions and under certain policies in the USA.

Akyüz et al., (2009) examined the technological and economic feasibility of a hybrid system to meet the energy needs of a typical commercial poultry farm independent of the electricity grid in order to economical evaluate the hybrid renewable energy systems in the industrial poultry sector. In the study, carried out in the chicken farm operating in Balıkesir province, different systems were designed to meet the demand for the load by examining the system energy cost, operating hours of diesel generator, unacceptable loads, excessive electricity generation and fuel saving.

In the study conducted by Dagtekin, (2012) in order to meet the electricity demand of the evaporative cooling (fan-pad) system of a poultry house with a capacity of $20.000,0$ broilers, the amount of electricity produced between June and September was $2.500,0 \mathrm{kWh}$. It was shown that the use of this energy produced in the operation of the cooling system and the rest in the mechanisms such as lighting and feed mechanization will significantly reduce the electrical charge of the enterprise. In addition, the net amortization time of the PV electricity generation system is 9.2 years and the electricity generation cost is determined as $0.1100 \mathrm{TL} \mathrm{kWh}^{-1}$.

Erensoy et al., (2015) examined the relationship between consumption and season in order to determine energy use characteristics in a fully environmentally controlled poultry house with $70.000,0$ laying hens. They found that the average electricity consumption per 1000 chickens was $1.480 \mathrm{kWh}_{\text {year }}{ }^{-1}$. In the study, where the seasonal effect on the energy consumption profile of the houses was also significant, the highest electricity consumption rates were observed in summer by $88 \%$ (ventilation-cooling), autumn by $62 \%$ (ventilation-lighting) and winter by $51 \%$ (ventilation-lighting). It has been concluded that increasing the energy efficiency in ventilation, cooling and lighting applications and/or the preference of renewable energy sources will provide significant savings in fully environmentally controlled poultry houses.

Regarding the studies conducted, the use of renewable energy in animal barns was generally applied in poultry houses. In dairy cattle barns electricity is required for several operations such as milking, milk storage, lighting and ventilation. Therefore, energy cost is one of the basic management costs for barns. On the other hand, studies regarding the use of solar energy in dairy cattle barns have not been found in extensive literature searches. At the 
The Effect of Building Orientation on Utilization of Solar Energy in Dairy Cattle Barns

same time, Bilgili and Aybek, (2019) analyzed 100 scientific studies (57 articles, 29 theses, 15 reports and 5 papers) to evaluate in terms of the requirements of scientific work made the last 40 years in Turkey about structural and mechanization features of dairy cattle barns stated that there is no research on the use of renewable energy sources in dairy cattle barns.

In the agricultural sector, the livestock industry where electricity energy is mostly consumed except for house is dairy cattle farming. The correct identification of dairy cattle farms' power and energy needs in mechanization works in Turkey is very important to eliminate the difficulties to be faced in the future energy production and distribution (Kasap, 1985).

The annual amount of electricity required for the barn considered in the study was calculated as $25.200,0 \mathrm{kWh}$. According to the results obtained from PVSOL software, the amount of electrical energy produced in North-South $(\mathrm{N})$ oriented panels is $179.453,0 \mathrm{kWh}$, whereas the amount of electrical energy produced in East-West (E) direction is $159.655,0 \mathrm{kWh}$. The amounts of electrical energy obtained in Northeast-Southwest (NE) and NorthwestSoutheast (NW) orientations are 175.950,0 kWh and 138.245,0 kWh, respectively (Table 1).

Table 1. The amount of energy consumed annually and produced in the panels

\begin{tabular}{cccc}
\hline $\begin{array}{c}\text { Barn } \\
\text { Direction }\end{array}$ & $\begin{array}{c}\text { Number of dairy } \\
\text { cattle available } \\
\text { (head) }\end{array}$ & $\begin{array}{c}\text { Annual amount of } \\
\text { energy required for } \\
\text { barn (kWh) }\end{array}$ & $\begin{array}{c}\text { Annual amount of } \\
\text { energy to be produced } \\
\text { in panels (kWh) }\end{array}$ \\
\hline N & 50 & $25.200,0$ & $179.453,0$ \\
E & 50 & $25.200,0$ & $159.655,0$ \\
NE & 50 & $25.200,0$ & $175.950,0$ \\
NW & 50 & $25.200,0$ & $138.245,0$ \\
\hline
\end{tabular}

The energy consumption value of the barn is constant in all 4 directions throughout the year. However, the amount of energy production varies according to the direction of the panel and the season. In general, the highest energy production is obtained in June, July and August, while the lowest production is observed in December, January and February (Figure 2, 3, 4 and 5).

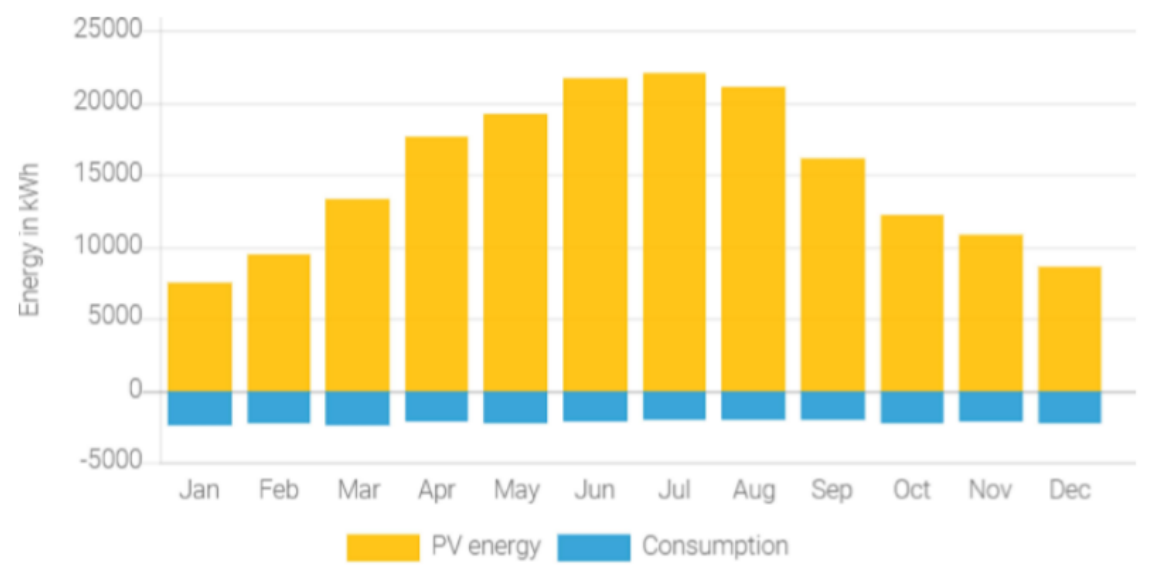

Figure 2. North-South (N) direction energy production and consumption 


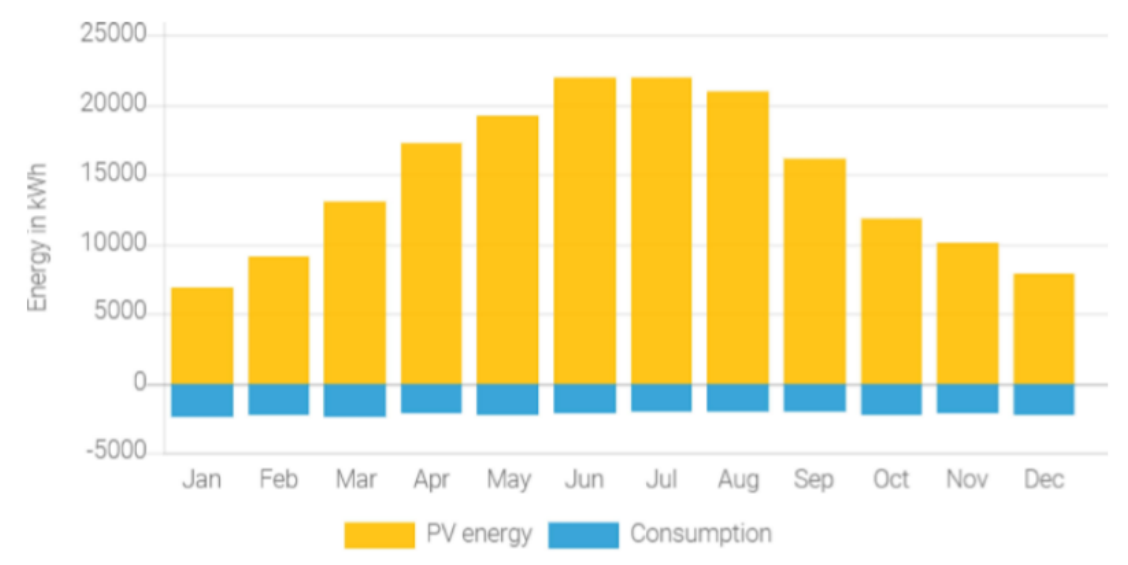

Figure 3. Northeast- Southwest (NE) direction energy production and consumption

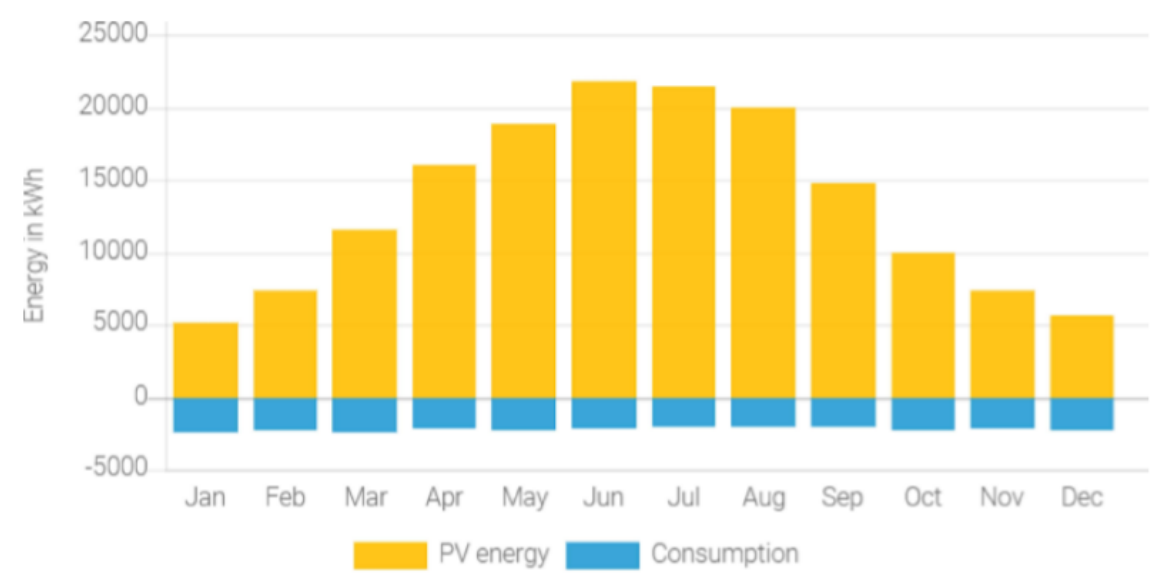

Figure 4. East-West (E) direction energy production and consumption

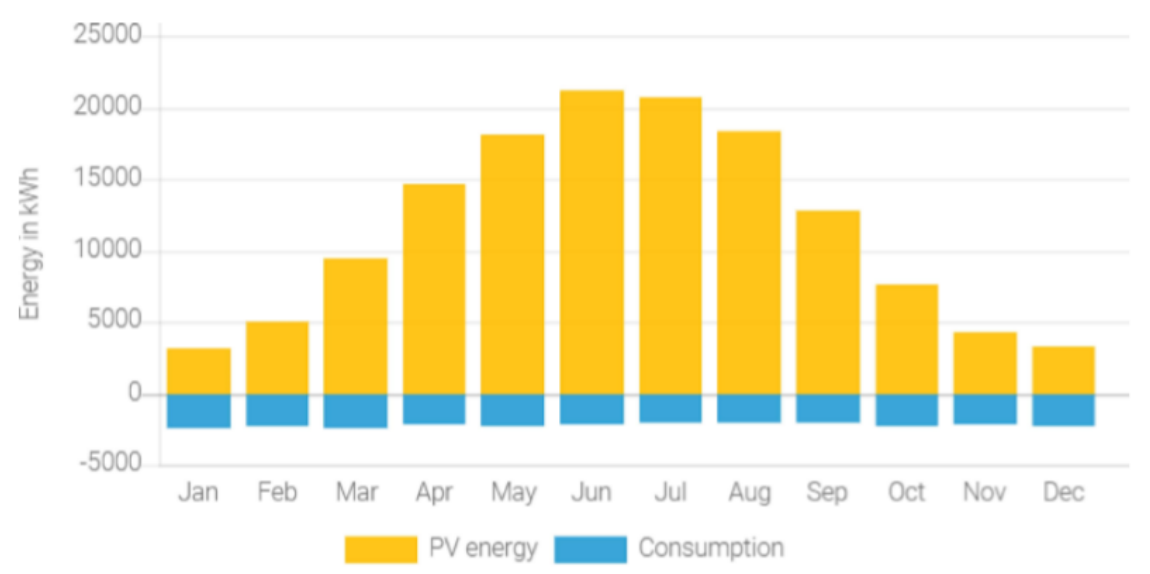

Figure 5. Northwest-Southeast (NW) direction energy production and consumption

\section{Conclusions}

Monthly energy production and consumption graphs for each orientation are given in Figure 2-5. Energy requirement of the barn was considered as constant $(25.200,0 \mathrm{kWh})$ for all months. The highest energy production in June, July and August; the lowest energy production was realized in December and January. However, even in January when energy production is minimum, more energy production than the barn's requirement was achieved. 
In other words, if the solar energy system is used in the barn considered in the study, the energy need could be met throughout the year without any problems.

The amount of electrical energy produced from all orientation options meets the needs of the barn but the highest production was obtained from the North-South orientation $(179.453,0 \mathrm{kWh})$. Considering that the excess electricity produced will be sold to the electricity company, it seems that the most suitable option is to choose orientation in which the maximum electrical energy production is achieved.

According to the long-term meteorological data of the region, since the dominant wind direction in the region is Northeast, it would be appropriate to orientate the barn in the North-South direction in order to increase the efficiency of natural ventilation and to better benefit from solar energy.

Despite the high initial investment costs, PV systems have a 10-year non-fail guarantee and a 25 -year operating guarantee, and maintenance costs are very low. Farmers using this system will make significant gains in the long run. For this reason, studies should be carried out and encouraged to widespread of solar energy, which is one of the renewable energy sources that can be an alternative to traditional energy sources.

The use of electrical energy, which is one of the serious input costs in animal production, negatively affects the prices of meat, milk and other animal products, and the producer's competition chance decreases. On the other hand, the issues of environmental problems that have increased in recent years and the reasons of environmental pollution by dairy cattle enterprises are on the agenda. Therefore, by using solar energy, both input costs will be saved and environmental pollution will be prevented by reducing $\mathrm{CO}_{2}$ emissions from dairy cattle barns.

As a result of the production of electrical energy with $\mathrm{PV}$, it is possible to create a chance for small enterprises to struggle, for medium-sized enterprises to develop, and for large enterprises to compete in the national and international market. 


\section{References}

Akyüz, E., Bayraktar, M., Oktay, Z. (2009). A feasibility study on hybrid renewable energy systems for the industrial broiler sector: An application. Journal of Balıkesir University Science and Technology Institute, Volume: 11, Issue 2, p. 44-54.

Anonymous (2014). TMMOB Chamber of Mechanical Engineers. “Turkey's Energy View” No: MMO/2014/616, Ankara.

Anonymous (2015a). Energy and Natural Resources Ministry. Information Center, "Sun” http://www.enerji.gov.tr/tr-TR/Sayfalar/Gunes , (Access date: 06.06.2015).

Anonymous (2015b) ECA "Solar Energy Systems" http://www.elginkan. com.tr/assets/media/mediaFile_52f889fc17d27.pdf. (Access date: 06.06.2015).

Anonymous (2017). Bursa Agricultural Investment Guide. Ministry of Food, Agriculture and Livestock, Strategy Development Department, Agricultural Investor Advisory Office, Bursa, 2017.

Bayraktar, K G. (2016). “Güneş Ülkemizin Enerji Geleceğidir.” 13 (Saha yayın), 52-56.

Bhol, R., Dash, R., Pradhan, A., Ali, S. (2015). Environmental effect assessment on performance of solar PV panel. Paper presented at the Circuit, Power and Computing Technologies (ICCPCT), International Conference on.

Bilgili E., Aybek A. (2019). Evaluation in Terms of Requirements in Application of Carried Out Scientıfic Studies for Structural and Mechanization Properties of Darry Cattle Farms in Turkey. Çukurova II. International Multidisciplinary Studies Congress, Full paper, p: 817-833. 26-28 April, Adana.

Byrne, J., Glover, L., Hegedus, S., Vanwicklen, G. (2005). The Potential of Solar Electric Applications for Delaware's Poultry Farms. Working paper. Center for Energy and Environmental Policy, University of Delaware.

Collar, C., Shultz, T., Peterson, N., Wubishet, A. (2000). Higginbotham G. Dairy and Livestock, California Dairy Energy Project, Research Report, California.

Dagtekin M. (2012). Tecno-ekonomic Feasibility Analysis of Solar Energy Use in Cooling of Broiler Poultry Houses. Cukurova University Journal of the Faculty of Agriculture, 27 (2): 11 - 20.

EEG (2016). The EU Project BETTER-Introduction to Modelling Framework. (Access date: 28.10.2016). http://better-project.net/sites/default/ files/Introduction to the modeling framework_ TUWIEN. pdf.

Erensoy, K., Altan, A, Bayraktar, H. (2015). Characteristics of Energy Usage and Energy Savings Opportunities in Environmentally Controlled Egg Production Houses. 9. National Animal Science Congress (Konya), Full Text Book, September 3-5. pp: 495-500.

Irwanto, M., Irwan, Y., Safwati, I., Leow, W.-Z., Gomesh, N., 2014. Analysis simulation of the photovoltaic output performance. Paper presented at the Power Engineering and Optimization Conference (PEOCO), IEEE 8th International.

Kasap A. (1985). Optimum Use Limits of Electrical Energy in Dairy Cattle Enterprises. $9^{\text {th }}$ National Agricultural Mechanization Congress, May 20-22, Adana.

Kurc, H. C. and Kocaman I. (2016.) Examination of Cattle Animal Farms Based On Structural Properties in The Tekirdag-Malkara Region Journal of Tekirdag Agricultural Faculty, 13 (04): 84-91.

Mohtasham, J. (2015). Renewable Energies. Energy Procedia, 74, 1289-1297.

Ozden, T., Karaveli, A B., Akinoglu, B G. (2020). Comparison of the Models of Solar PV Performance Calculations for Ankara - Middle Anatolia. European Journal of Science and Technology, (18), 54-60.

Ozyürek, S., Kocyigit, R., Tüzemen, N. (2014). Structural Features of Dairy Farmers in the Erzincan: The Example of Çayırlı District. Journal of Tekirdag Agricultural Faculty, 11 (3): 19-26.

Peterson R. (2008). Energy Management for Dairy Farms. Presentation at the Farm Energy Audit Training for Field Advisors Workshop.

Sharma, R., Gidwani, L. (2017). "Grid connected solar PV system design and calculation by using PV*SOL premium simulation tool for campus hostels of RTU Kota," 2017 International Conference on Circuit, Power and Computing Technologies (ICCPCT), Kollam, pp. 15 .

Soyak, A., Soysal, M. I., Gürcan, E.K. (2007). In Investigation of Structural Properties of Dairy Enterprises and Morphologic Characteristics of Black and White Cattle in Tekirdag Province. Journal of Tekirdag Agricultural Faculty, 4 (3): 297-305.

Thomas R. (2003). Photovoltaics and architecture: Taylor \& Francis, New York.

Tuik (2019). Turkish Statistical Institute. Livestock Statistics for Bursa Province, 2018. (Access date: 20.08.2019).

Türkboyları E.Y., Yüksel A. N. (2021). Use of Solar Panel System in Vermicompost (Worm Manure) Production Facilities as Source of Energy. Journal of Tekirdag Agricultural Faculty, 18 (1), 91-97.

Yaslioglu E., Ilhan H. (2016). An Analysis of Dairy Cattle Production in Southern Marmara in terms of Heat Stress. Journal of Tekirdag Agricultural Faculty. 13 (04). 